\title{
Genetic Diversity Studied on Some Polyembryoinc\& Monoembryonic Mango Genotypes using Morphological and Molecular markers
}

\author{
Ibrahim, A.M.F ${ }^{1}$ A.M.Attla ${ }^{1}$ N.A.Awad ${ }^{2}$ H.M.EL-Shishatawy ${ }^{3}$ and S.A.Ali. ${ }^{2}$ \\ ${ }^{1}$ Pomology Department, Faculty of Agriculture, Alexandria University. \\ ${ }^{2}$ Fruit Breeding Department Horticulture Research Institute, Agriculture Research center (ARC), \\ Cairo, Egypt. \\ ${ }^{3}$ Agriculture Genetic Engineering Research Institute (AGERI), Agriculture Research center (ARC), \\ Cairo, Egypt.
}

Received on: $13 / 12 / 2015$

Accepted: $31 / 1 / 2016$

\begin{abstract}
This study was carried out during 2013 and 2014 growing seasons on eight years old trees to study the cross among some mango cultivars (Mangifera indica) mono- embryonic (Keitt - Zill - Sensation) and polyembryonic mango (13/1Sabra- Peetch) on the orchard of the Tropical fruit garden in Horticulture Research Institute, Giza, Egypt. Physical and chemical characteristics of fruits were study besides of molecular characterization (RAPD). The data showed that the Keitt cultivar had significantly higher average fruit lengths. On the country, Zill cultivar recorded the lowest one. Also, Keitt cultivar had the biggest in weight fruit followed by Sensation, but Peetch and Zill produced the smallest one. Furthermore, Zill fruit gave the highest values of non-reducing sugar and the lowest one was clear in Peetch fruit. Meanwhile, the total sugar percentages revealed that Zill cultivar recorded the greatest content. The highest value of the acidity percentage was found in Sabra fruit and the lowest value was found in Zill fruit. However, the highest Vit.C was clear in Keitt fruit and the lowest one was shown in 13/1 fruit. Moreover, genetic studies was used to determined genetic variability, relationship and identify unique molecular marker characterizing six mango genotypes and their hybrids using eight of the RAPD primers. Number of polymorphic bands ranged from 5 to 24 , detecting 99 polymorphic bands with an average 12.3 bands / primer. The highest number of polymorphic bands (24) was obtained with primer OPO16, representing the highest percentage $(100 \%)$ of polymorphism. H13 was closely related to Keitt genotype, H5 was closely Zill genotype and Sensation genotype revealed genetic relation with hybrids (H11, H1, H10 and H12).
\end{abstract}

Key words: Mango- Monoembryonic- Polyembryonic- RAPD.

\section{INTRODUCTION}

Mango (Mangifera indica L.) is a tropical tree fruit; usually the tree flowers in spring and produces attractive fruits in June or July. Mangoes، like many other tropical fruit trees, does not flower consistently. Mango cultivation occupying more than 80 countries including Egypt. The total mango production in are increment year after year. Although family Anacardiaceae includes many genera, however, the genus Mangifera is the most predominant one, this genus including more than 60 species according to Saibyasachi, 2003). Due to its delicious fruit, the species indica the most important species from the standpoint of the growers and consumers as will as widely grown throughout the tropical regions and many subtropical areas as well. The somatic chromosome number of such a species is $(2 \mathrm{n}=40)$ according to Mukherjee, 1950). The species consist of two ecogeographic races that can be distinguished on the basis of their seed type, i.e., monoembryonic/subtropical and polyembryonic / tropical (Mukherjee, 1998). Statistics of 2012 provided by the Ministry of Agriculture and Land Reclamation indicate that, a total of 209040 Fadden are planted to mango and generating a total of 505741 tons. The average yield per Fadden is 3.33 tons in Egypt approximately one half of what commercial orchards are capable of producing (Agricultural Statistics, 2012).

In mango breeding programs, cultivars identification still relies on morphological characteristics. However, many cultivars cannot be rapidly distinguished by morphological indices, particularly if they are closely related. Furthermore, phenotype identification based on morphological traits is subject to environmental variation (Nielson, 1985). The field of molecular biology has provided tools suitable for rapid and detailed genetic analysis of higher organisms including agriculture species (Williams et. al., 1990).However, breeding programs based on intervarietal hybridization may produce new improved cultivars for mango growers. Mango hybrids have been obtained by controlled or open crosses. In the last one, it is important to identify the male parent because it is useful for the genetic cultivar history, thus it is important for planning further improvements. 
The aim of the present study is to cross among some monoembryonic and polyembryonic mango cultivars to produce some new germplasm, and evaluate of some physical characteristics \& certain chemical constituents of fruit and subsequently, identity polymorphic DNA markers useful for distinguishing the studied monoembryonic and polyembryonic mango genotypes using RAPD markers in parents and hybrids, to incorporating them in the breeding programs and for future use.

\section{MATERIALS AND METHODS}

Morphological and chemical studies:

\section{A- Morphological characteristics}

The present work was carried during 2013 2014 growing seasons to study the cross among some mango cultivars (Mangifera indica) monoembryonic (Keitt- Zill- Sensation) and polyembryonic mango (13/1- Sabra- Peetch). The trees were eight years old, grown in sandy soil, at a spaced $2 \times 4 \mathrm{~m}$ on the orchard of the Tropical fruit garden in Horticulture Research Institute, Giza, Egypt. Fertilization, pruning as well as pest and disease control. Drip irrigation system is used. Each cultivar (treatment) was represented by five trees, as for as possible uniform in size and vigour. Trees were selected from each cultivar (accessions) used in this investigation, i.e., each selected tree was replicated five times.

At the flowering time, the infloresencences of monemberyonic cultivars on the tagged shoots was sprayed with Maleic Hydrazide at $(750 \mathrm{ppm})$ to induction of pollen sterility, and remained one hour to dry. The pollen grains were taken from polyembryonic cultivars at 10 clocks in the morning to pollinate monemberyonic once, and bagging with packing paper, the bagging paper remained for 30days to the end of pollination period according to Ravi et. al. (2002).

At harvest time for each cultivar in both 2013 and 2014 seasons. Samples of 10 mature fruits on the tagged shoots were taken at random from each experimental tree. The following traits were measured.

\section{Fruit physical characteristics}

Average fruit length and diameter $(\mathrm{cm})$ were measured for each individual fruit using a vernier calipar. Fruit weight, flesh weight, Peel weight and stone weight $(\mathrm{gm})$ were determined for each cultivar according to IPGRI, 2006.

\section{B- Fruit chemical studies}

Fruit samples were taken to study some biochemical properties in the Laboratory of Pomology Department and the Biotechnology Laboratory of the Horticulture Research Institute. The starch \% was determined in $0.1 \mathrm{gm}$ of the residue by hydrolysis with concentrated HCL for 3 hours under reflux condencer (A.O.A.C.1980). The total reducing sugars $\%$ power was determined according to the method of Malik and Singh (1980), and the factor 0.9 was used to calculate the starch (Woodman, 1941). The reducing sugar was determined by the Nelson arsenate-molybdate colorimetric method (Dubois et al., 1956). The nonreducing sugars $\%$ were calculated by the difference between the total and the reducing sugar. The total sugars $\%$ were determined clorimetrically using phenol and sulphuric acid according to Malik and Singh (1980). The percentage of total soluble solids $\%$ in the fruit juice was determined using a hand refractometer. Fruit juice acidity was determined according to the A.O.A.C. (1980) by titration with $0.1 \mathrm{~N}$ sodium hydroxide using phenolphthalen as an indicator and expressed as citric acid percentage. Vitamin $\mathrm{C}$ (ascorbic acid) content was determined in fruit juice using 2, 6dichlorophenol-indo-phenol blue dye as $\mathrm{mg}$ ascorbic acid per100 ml juice (A.O.A.C.1980).

\section{DNAfingerprint}

Total genomic DAN was extracted from young green mango leaves, using modified CTAP protocol (Porebski et. al., 1997).RAPD fragments were amplified according to (Machado et. al., (1996). Amplification reaction for RAPD consisted of 1.5 $\mathrm{mM} 10 \times$ buffer, $1.5 \mathrm{mM} \mathrm{Mgcl}_{2}, 100 \mu \mathrm{M} \mathrm{dNTP}_{\mathrm{s}}(25$ $\mu \mathrm{M}$ each), $0.2 \mu \mathrm{M}$ primer, $1 \mathrm{U}$ Taq polymerase, 50 ng of DNA and sterile water up to $25 \mu \mathrm{L}$. RAPD amplification was conducted as follow: an initial step at $94^{\circ} \mathrm{c}$ for $5 \mathrm{~min} .40$ cycles for each cycle 1 min at $94{ }^{\circ} \mathrm{c}, 1 \mathrm{~min}$ at $37^{\circ} \mathrm{c}$ and $2 \mathrm{~min}$ at $72^{\circ} \mathrm{c}$ and final extension step at $72^{\circ} \mathrm{c}$ for $5 \mathrm{~min}$.

Statistical analysis

Data were statistically analyzed using randomized complete block design (R.C.B.D) in five replications in each season. Least significant differences (L.S.D0.05) used or comparison between the six cultivars means according to Gomez and Gomez (1984).As for cluster analysis data: based on RAPD marker analysis was detected for mango cultivars. Different genetic relationships were established thought PAST program software according to Wolf et al. (1999).

\section{RESULTS AND DISCUSSION}

Morphological and chemical studies:

A-Morphological characteristics

Fruit physical characteristics

The data of Table 1 represent the average fruit length of different studied cultivars in both 2013 and 2014 seasons. The obtained data of both seasons revealed that, Keitt cultivar had significant the highest average of fruit lengths (10.65 and $10.55 \mathrm{~cm}$ for 2013 and 2014 seasons respectively). On the country, Zill cultivar recorded the lowest significant average of fruit length (7.67 and $7.70 \mathrm{~cm}$ for 2013 and 2014 seasons, respectively). 


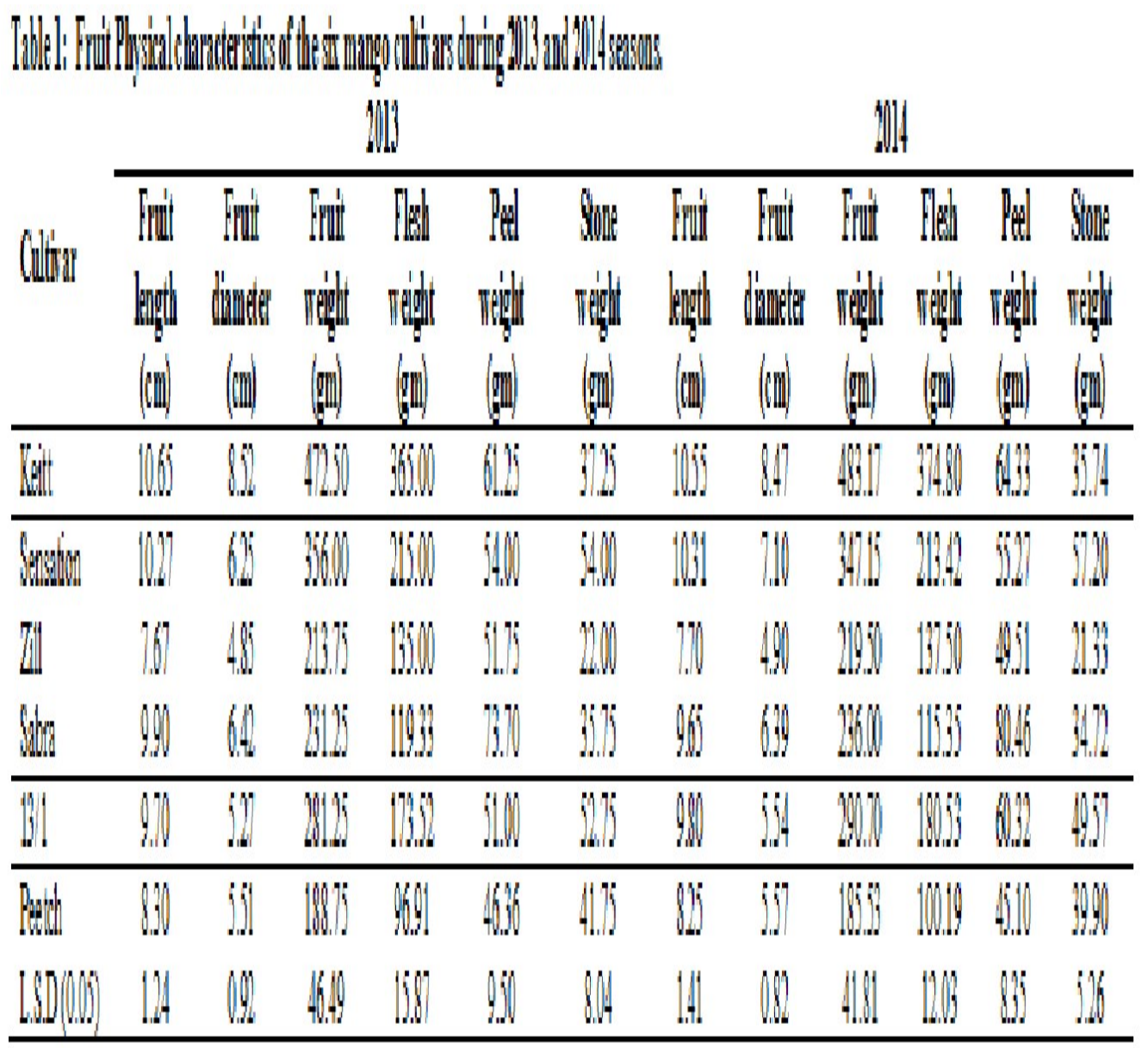



The average fruit length of Keitt cultivar did not significantly differ and those of Sensation, Sabra, and 13/1 cultivars in the both seasons.

According to fruit diameter, the data showed that highest values in both seasons was recorded in Keitt cultivar (8.52 and $8.47 \mathrm{~cm}$, respectively), while the lowest one was recorded by Zill cultivar (4.85 and $4.90 \mathrm{~cm}$ respectively). The statistical analysis indicated that there were no significant differences between fruit diameter of Zill and both Batch and 13/1 cultivars. Also there were no significant differences between fruit diameter of Sensation and Sabra cultivars.

In addition, Keitt cultivar recorded the highest values of fruit weight in both seasons (472.50 and $483.17 \mathrm{~g}$, respectively), while the lowest was found in Peetch cultivar in both seasons (188.75 and 185.53 (g) respectively). The differences between Peetch cultivar on one side, Sensation and Keitt on the other Sabra cultivars were significant in the both seasons. only furthermore, the data revealed that, Keitt cultivar exhibited the highest flesh weight values (365.00 and $374.80 \mathrm{~g}$ for 2013 and 2014 seasons, respectively), while, the Peetch cultivars gave the lowest one in both seasons (96.91 and100.19 g, respectively) as compared with the other studied cultivars.

The data of 2013 and 2014 seasons revealed that the Sabra cultivar gave considerably greatest average fruit peel weight (73.70 and $80.46 \mathrm{~g}$, respectively), while Peetch cultivars gave the lowest ones in the both seasons (46.36 and $45.10 \mathrm{~g}$, respectively) than those of the other studied cultivars.

It was obvious that, Sensation recorded the highest average of stone weight in both seasons (54.00 and $57.20 \mathrm{~g}$, respectively) as compared with that of the other studied cultivars. On the contrary, Zill cultivar gave the lowest ones in both seasons (22.00 and $21.33 \mathrm{~g}$, respectively), whereas, the other studied cultivars had intermediate values between the two extremes with significant differences in stone cases.

The results relating to morphological characteristics are in harmony with those obtained Ibrahim and Kholif (1999), who stated that the length of Keitt, Sensation fruit cultivars ranged from $(7.5-9 \mathrm{~cm})$ and $(9-11.5 \mathrm{~cm})$, respectively. In addition, Hamdard et al. (2004) determined physical properties of eight mango cultivars and stated that the average weight of the fruit per cultivar was greatly varied from one cultivars to another; the recorded data showed that Anwar Retaul had the lowest value $(108.0 \mathrm{~g})$ and Fajri had the highest one (409.2 g). Moreover, they found the maximum pulp value (80\%) was in Langra mango cultivar cultivars and stone weight content ranged from $(9.6-18 \%)$ of fruit weight. Majumder et al. (2011) and Barua et al. (2013) concluded the same results of (length, weight, diameter and peel weight).

The results of the present study indicated that the great variation regarding the physical characteristics of the fruit of the studied cultivars could be due to the differences between the genetic constituents of the different studied cultivars.

\section{B- Fruit Chemical constituents}

As for the starch percentages in fruit pulp of the studied cultivars, the data of Figure (1) showed that Peetch cultivar had the highest values of starch percentages in 2013 and 2014seasons (2.30and 2.60 $\%$, respectively), while the lowest values were recorded by Sensation cultivar (1.11 and 1.15\%, respectively. Whereas, the other studied cultivars had intermediate values. However, it was obvious that Sensation cultivar recorded the highest percentage of reducing sugar in both seasons (13.48and $12.30 \%$ respectively) in comparison with those of the other different studied cultivars. On the contrary, 13/1 cultivar gave the lowest reducing sugar percentages in both seasons (5.67 and $6.34 \%$ respectively), however, there no significant differences between the13/1 cultivar and those Peetch and Keitt in both seasons Figure (2).

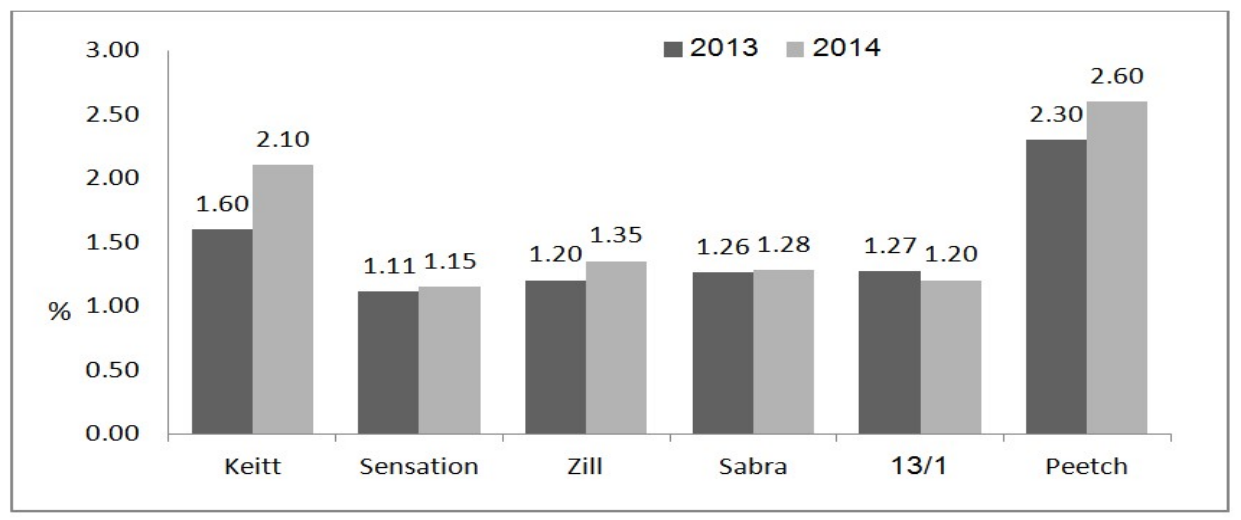

Figure 1: Starch content $(\%)$ in fruits of six mango cultivars during 2013 and 2014 seasons. 


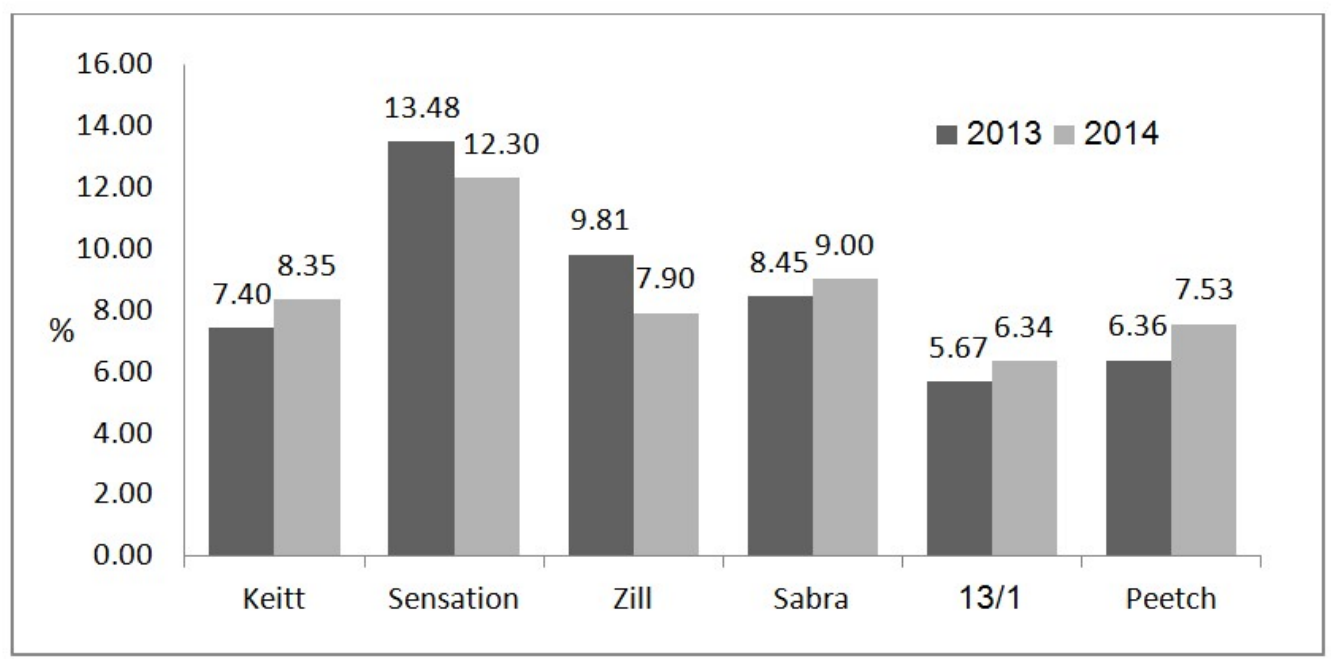

Figure 2: Reducing sugar percentage in fruits of six mango cultivars during 2013 and 2014 seasons.

As shown in Figure (3) the highest values of non-reducing sugar were found in fruits of Zill cultivar in both 2013 and 2014 seasons (18.57 and $18.92 \%$, respectively). On the other hand, the lowest ones recorded by Peetch cultivar in both seasons (6.06 and $6.00 \%$, respectively), while the other remaining cultivars had intermediate values between two extremes with significant differences among them. Meanwhile, the total sugar percentages revealed that Zill cultivar recorded the greatest content (28.38 and 26. $82 \%$ for 2013 and 2014 seasons, respectively). On the other hand, the lowest total sugar percentage was found in fruit pulp Peetch cultivar $(12.42 \%$ and $13.53 \%)$ for both seasons, respectively. Statistical analysis indicated that there were significant differences in total sugar percentage in fruit of Zill cultivar as compared with of the other studied ones, except Sensation cultivar. Figure (4).

In both 2013 and 2014 seasons, the highest TSS percentage in fruits was found in Sensation cultivar, While the lowest TSS percentage in 2013 found in $13 / 1$ cultivar $(12.20 \%)$, and Peetch cultivar $(11.87 \%)$ in 2014 season only in Figure (5). Meanwhile, the highest values of acidity percentage was found in Sabra cultivar (0.67 and 0.71\%, respectively), while the lowest ones was found in Zill cultivar ( 0.29 and $0.28 \%$, respectively) in both seasons as shown in Figure (6).

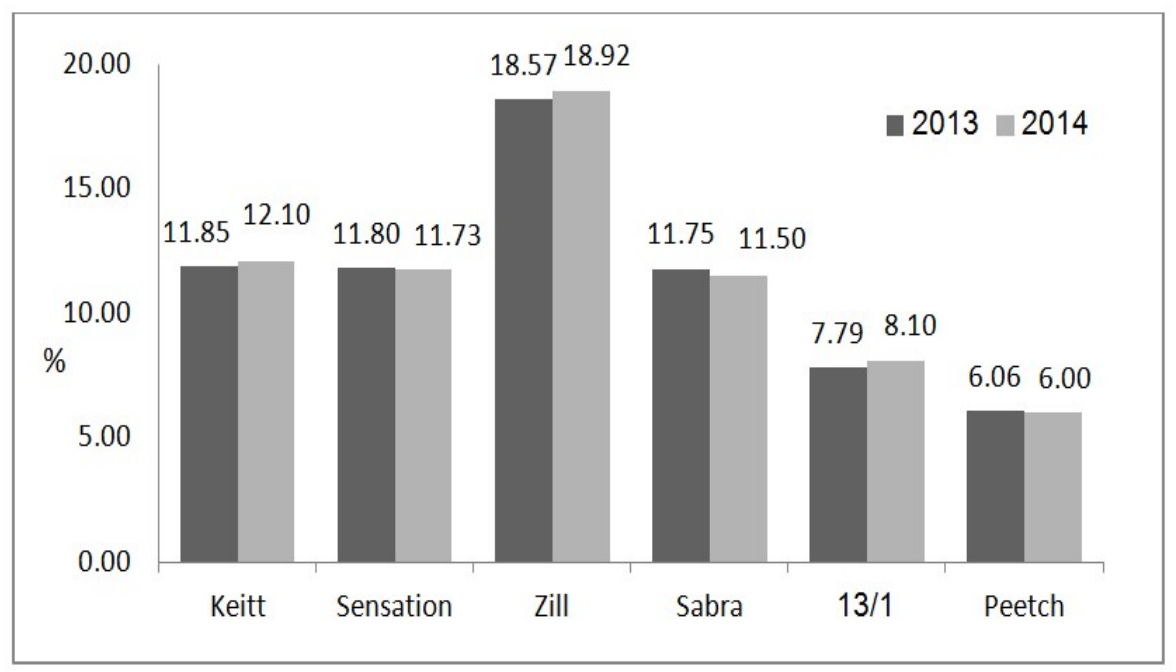

Figure 3: Non- reducing sugar percentage in fruits of six mango cultivar during 2013 and 2014 seasons. 


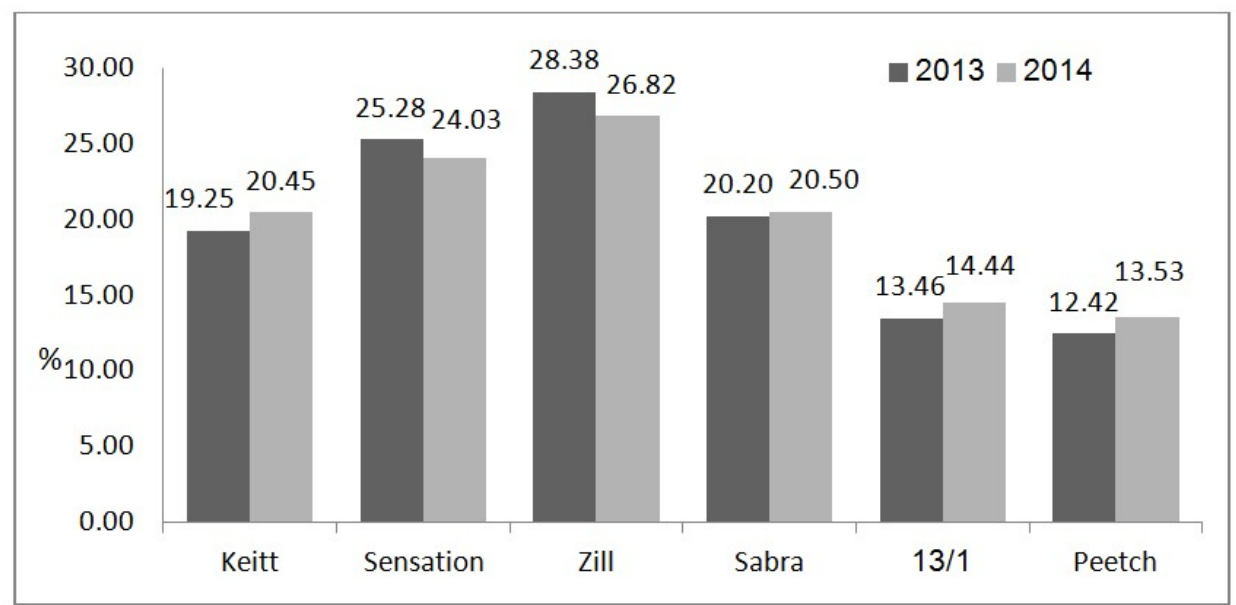

Figure 4: Total sugar percentage in fruits of six mango cultivars during 2013 and 2014 seasons.

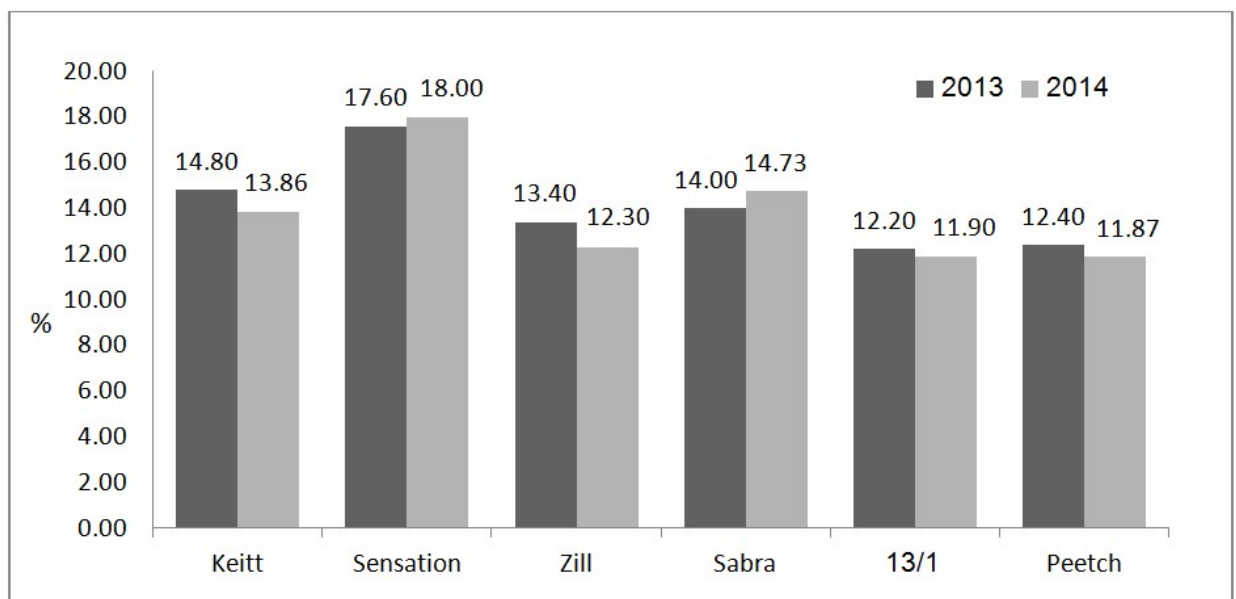

Figure 5: Juice TSS percentages in fruits of six mango cultivars during 2013 and 2014 seasons.

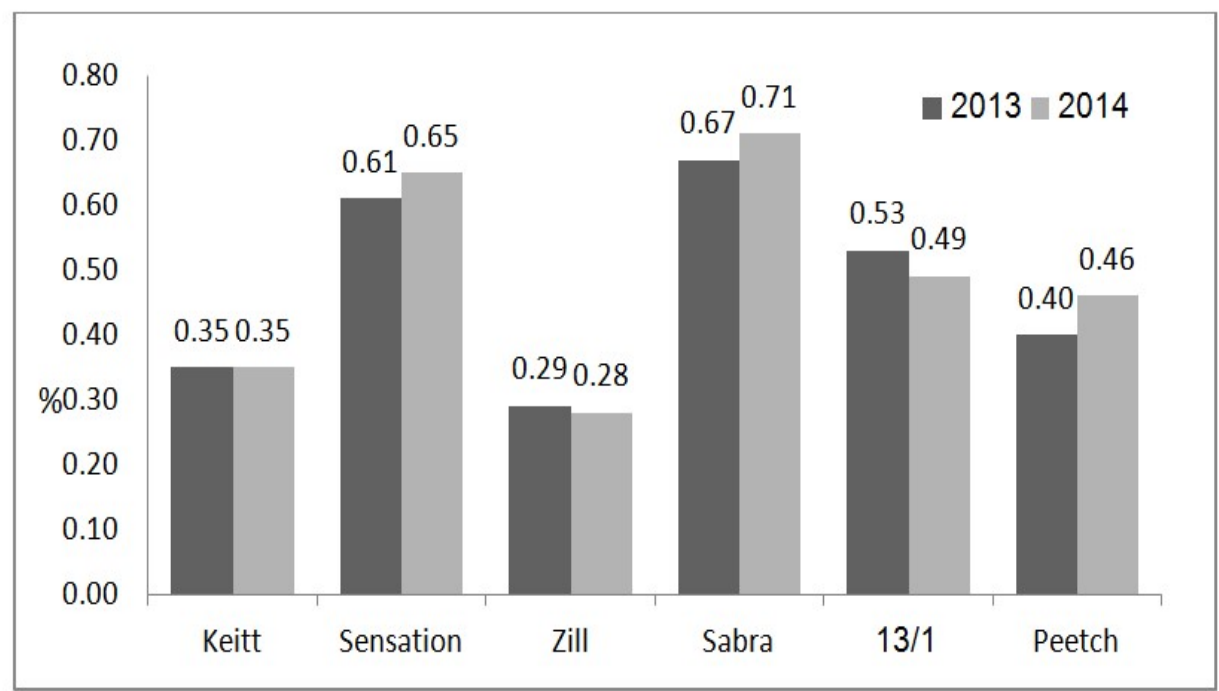

Figure 6: Juice acidity percentages in fruits of six mango cultivars during 2013 and 2014 seasons. 

However, it is clear that Keitt cultivar produced the highest significantly average Vit.C in both experimental seasons $(23.50$ and $22.60 \mathrm{mg} / \mathrm{ml}$ juice respectively) as compared with that of the other studied cultivars (Figure 7). In the meantime, 13/1 cultivar had the lowest average content of Vit.C (12.00 $\mathrm{mg} / \mathrm{ml}$ juice) as compared with that of studied cultivars, except Sabra in the first seasons.

In this regard, Majumder et al. (2011) found that the highest TSS percentage was $(28.26 \%)$ in M128 cultivar, and the lowest TSS is $(16.90 \%)$ in M120 cultivar. Anjum et al. (2014) studied the chemical constitute in fruit of eight mango cultivars (Aman Dusahri, Chaunsa, Black Chaunsa (Late), Anwar Ratual, Anwar Ratual No.12, Langra, Fajri and Sindhri. They showed that Langra contained maximum sugar content $(20.67 \%)$ followed by Samar Bahisht Chaunsa (20.34\%) and Anwar Ratual (20.33\%), while minimum sugar content was found in cv. Sindhri $(16.00 \%)$, and they reported that mango cultivars show marked variations in respect of vitamin $\mathrm{C}$ and found that the highest vitamin $\mathrm{C}$ contents were obtained from pulp of mango cv. Langra followed by Fajri. The lowest vitamin $\mathrm{C}$ was found in mango cv. Anwar Ratual.

DNA Fingerprint using RAPD markers:

Polymorphisms as detected by Randomly Amplified Polymorphic DNA (RAPD).

RAPD polymorphism results from using, generally, $10 \mathrm{bp}$ synthetic primers of random sequence. These oligonucleotides serve as both forward and reverse primers and usually are able to amplify fragments from 3-10 genomic sites simultaneously (Williams et al. 1990). This technique has been used extensively for varietal identification, phylogenetic relationships, parentage determination and marker-assisted selection in a wide range of plant species because of its simplicity (Cao et al., 1999 and Nebauer et al., 2000).

Eight primers were screened with the DNA of fourteen hybrids of mango and their parents. These primers generated reproducible and easily scorable RAPD profiles. These produced multiple band profiles with a number of amplified DNA bands ranging from 7 to 24 (Table2). The total number of bands produced by the tested primers was 111 with an average number of 13.8 bands / primer. While, the number of polymorphic bands ranged from 5 to 24, detecting 99 polymorphic bands with an average 12.3 bands / primer. A maximum number of 24 bands were amplified by primer OPO16, while the minimum number of fragments was amplified with primers OPZ18 (7). The highest number of polymorphic bands (24) was obtained with primer OPO16, representing the highest percentage (100\%) of polymorphism. Moreover, the size of the amplified fragments varied with the tested primers, it was ranged from $150 \mathrm{bp}$ to $1500 \mathrm{bp}$.

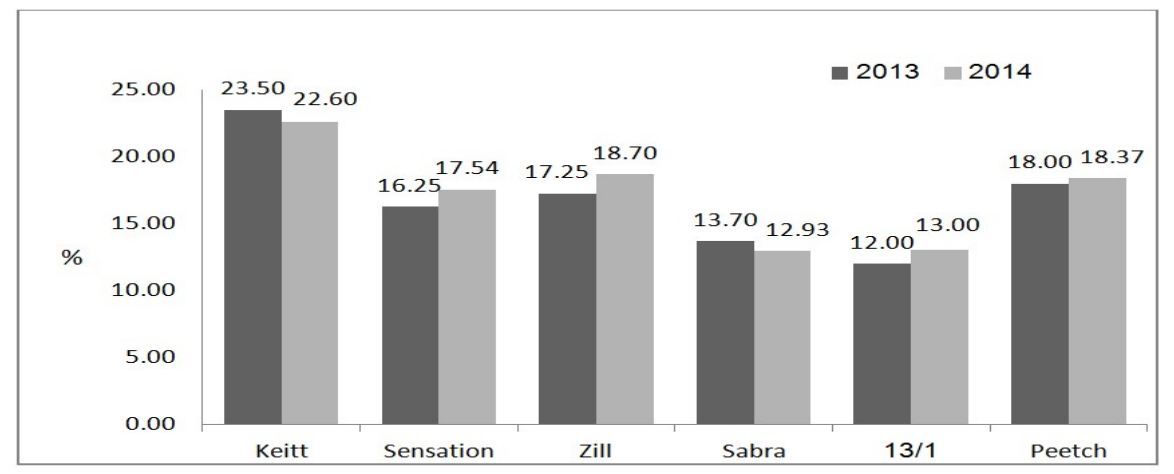

Figure 7: Ascorbic acid content in fruits of six mango cultivars during 2013 and 2014 seasons.

Table 2: The total number of ampicons; monomorphic ampicons, polymorphic ampicons and percentage of polymorphism as revealed by RAPD markers

\begin{tabular}{lcccc}
\hline Primer & $\begin{array}{c}\text { Total no. of } \\
\text { amplicons }\end{array}$ & $\begin{array}{c}\text { Monomorphic } \\
\text { amplicons }\end{array}$ & $\begin{array}{c}\text { Polymorphic } \\
\text { amplicons }\end{array}$ & $\begin{array}{c}\text { Percentage of } \\
\text { polymorphism }\end{array}$ \\
\hline OPB01 & 8 & 2 & 6 & 75.0 \\
OPC17 & 14 & 3 & 11 & 78.6 \\
OPO13 & 19 & 1 & 18 & 94.7 \\
OPO16 & 24 & 0 & 24 & 100 \\
OPO20 & 9 & 1 & 8 & 88.9 \\
OPZ18 & 7 & 2 & 5 & 71.4 \\
OPZ19 & 12 & 2 & 10 & 83.3 \\
OPZ20 & 18 & 1 & 17 & 94.4 \\
\hline Total & 11 & 12 & 99 & 89.2 \\
\hline Average & 13.8 & 1.5 & 12.3 & \\
\hline
\end{tabular}


In this respect, Samal et al. (2012) determined the genetic diversity among 65 mango genotypes including 20 commercial cultivars using RAPD and ISSR marker. Fifteen RAPD primers yielded 27 monomorphic and 129 polymorphic bands with an average percent $(85.71 \%)$. Also, Ravindra et. $a l$..(2014) mentioned that, out of 8 RAPD primers tested with ten mango accessions; four generated polymorphic bands. A total of 27 bands were obtained, of which all were polymorphic with an average of 7 bands per primer.

Cluster analysis among the tested hybrids and the parents:

The Dice RAPD-based coefficients of genetic similarity among the 14 hybrids of mango and their parents resulted in a dendrogram (Fig.8). The tested genotypes raised two clusters (A\&B), which were divided in four subgroups. The first subgroups was subdivided into two divission, the first included the two hybrids (H14 and H9), while the second one was divided into two subgroups. The first one included two hybrids (H12 and H10); while, the other one collected Sensation and two other hybrids (H1 and H11). The second group included 13/1, Peetch and Sabra which represent all the cultivar parents used in this study. However, the third subgroup was divided into two division, the first one contained the two hybrids ( $\mathrm{H} 2$ and $\mathrm{H} 3)$, while the other contained the three hybrids (H4, H7 and $\mathrm{H} 8$ ). On the other hand, the fourth subgroup was comprised of two division; one of them included hybrids (H5 and Zill genotype), meanwhile, the second one grouped 13/1 genotype, H6 hybrid and H13 hybrid. Majumder et al. (2011) examined sixty mango genotypes using RAPD analysis.The dendrogram classified these genotypes into two large groups (A and B). Both groups were divided into sub-groups. Cluster A consists of released and landraces genotype; while B includes a combination of exotic, indigenous as well as some local cultivars. Moreover, ten mango accessions were tested by RAPD markers rising two clusters. Clusters 1 consist of 3genotypes; meanwhile, Clusters II was the largest including 7 genotypes.

Genotype Identification by Unique RAPD Markers:

As shown in Table (3), the RAPD assay permitted the identification of 9 genotype by unique positive and/or negative markers. Eight genotypes were characterized by 11 positive unique RAPD markers. Among these eight genotypes, two were also characterized by negative RAPD markers. On the other hand, one genotype (peetch) was distinguished by negative RAPD markers only. Among the tested primers, three exhibited negative markers and six revealed positive markers. These identified 18 unique markers across the twenty tested genotypes. The RAPD primers generating the different markers and the markers approximate size are listed in Table (8). Hybrid $\mathrm{H} 2$ was characterized by the highest number of unique markers; three are negative and one positive marker. This was followed by $\mathrm{H} 1$ which revealed three positive unique markers, one of these markers resulted from primer OPZ18 and two from OPO16. On the other hand, the lowest number of unique markers was detected in H3, H4, H6, H11 and Sensation genotype which were identified by only one unique positive marker.

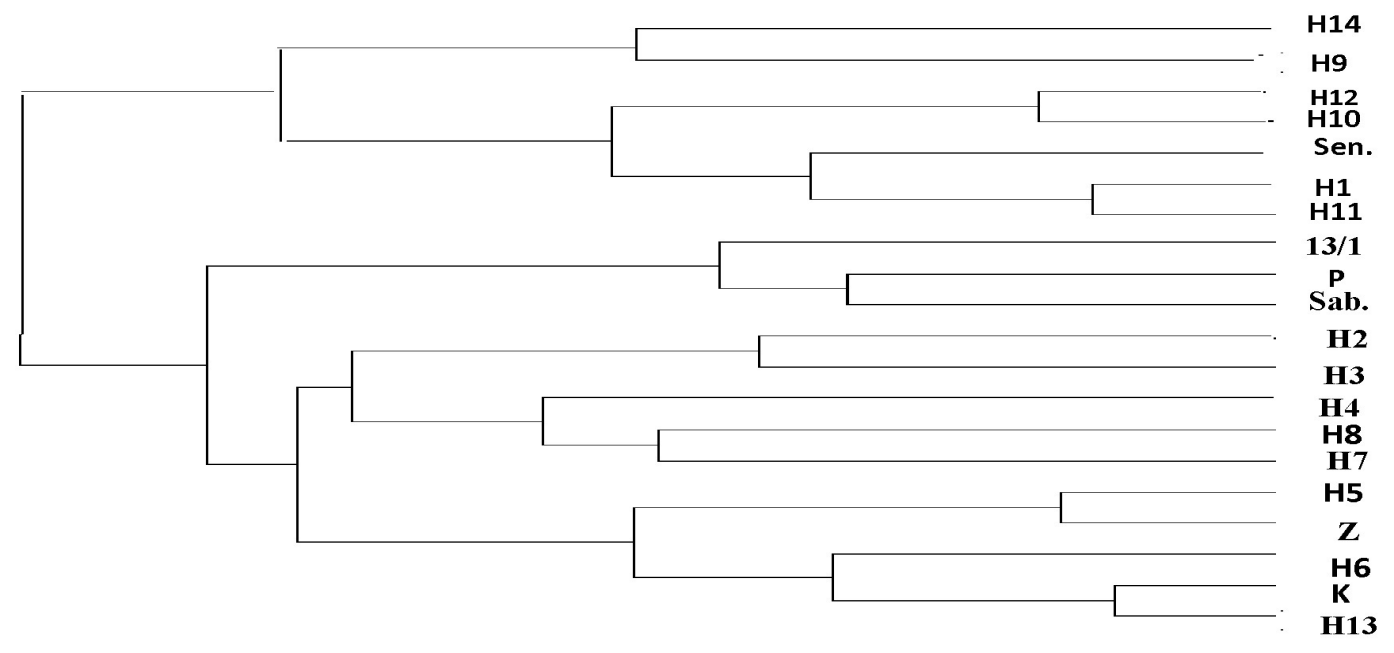

Figure 8: Dendrogram of correlation similarity using average linkage (Between Groups) among the different mango and hybrids cultivars based on RAPD results.

Parents $=$ Sensation $\times 13 / 1$ (H14and H9), Sensation $\times$ Peetch $(H 12$ andH10), Sensation $\times$ Sabra (H1 andH11), Zill $\times$ 13/1(H2\&H3), Zill× Peetch (H4\&H8), Zill $\times$ Sabra (H7\&H5), Kitt $\times$ Peetch (H6), Kitt $\times$ Sabra (H13). 
Table 3: The characterized genotype by unique positive and /or negative RAPD markers, marker size total number of markers identifying genotype.

\begin{tabular}{|c|c|c|c|c|c|c|c|}
\hline \multirow[t]{2}{*}{ Genotype } & \multicolumn{3}{|c|}{ 1-Unique positive marker } & \multicolumn{3}{|c|}{ 2-Unique negative marker } & \multirow[t]{2}{*}{ Grand Total } \\
\hline & $\begin{array}{l}\text { Size of the } \\
\text { Maker } \\
\text { band (bp) }\end{array}$ & Primer & $\begin{array}{c}\text { Total of } \\
\text { marker/ } \\
\text { accession }\end{array}$ & $\begin{array}{c}\text { Size of } \\
\text { the } \\
\text { Maker } \\
\text { band (bp) }\end{array}$ & Primer & $\begin{array}{l}\text { Total of } \\
\text { marker/ } \\
\text { accession }\end{array}$ & \\
\hline H1 & $\begin{array}{c}1306,800 \\
310\end{array}$ & $\begin{array}{l}\text { OPO16 } \\
\text { OPZ18 }\end{array}$ & 3 & ------ & $\begin{array}{l}---- \\
\end{array}$ & ------ & 3 \\
\hline $\mathrm{H} 2$ & 500 & OPC17 & 1 & $\begin{array}{c}350,650 \\
1200\end{array}$ & OPO13 & 3 & 4 \\
\hline $\mathrm{H} 3$ & 310 & OPC17 & 1 & ----- & $\begin{array}{ll}---- \\
-1\end{array}$ & 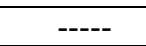 & 1 \\
\hline $\mathrm{H} 4$ & 495 & OPO16 & 1 & $\begin{array}{c}----- \\
\end{array}$ & $\begin{array}{ll}---- \\
\end{array}$ & $\begin{array}{ll}---- \\
\end{array}$ & 1 \\
\hline H6 & 400 & OPZ20 & 1 & $\begin{array}{c}----- \\
--1\end{array}$ & $\begin{array}{ll}---- \\
\end{array}$ & $\begin{array}{ll}---- \\
\end{array}$ & 1 \\
\hline H11 & 700 & OPO13 & 1 & ----- & 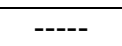 & 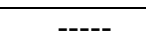 & 1 \\
\hline Sensation & 150 & OPO16 & 1 & ----- & ----- & ----- & 1 \\
\hline Keitt & 850 & OPZ20 & 2 & 850 & OPO20 & 1 & 3 \\
\hline Peetch & & & ----- & $\begin{array}{c}600,950 \\
1000\end{array}$ & OPC17 & 3 & 3 \\
\hline Genotype & & & 11 & & & 7 & 18 \\
\hline
\end{tabular}

1-Unique positive marker means: the bands that are present in one accessions but not found in the other terminal positive unique marker.

2-Unique negative marker means; in contract to the negative unique marker which are absent in specific genotype.

The size of these unique markers ranged from 150 to $1306 \mathrm{bp}$. Certain primers, were more informative than the others e.g., OPC17, and OPO16 since they identified the highest number of genotypes (3). The presence of unique RAPD markers among the tested genotype indicates the utility of the approach for fingerprinting purposes. The obtained results were in agreement with thefindings of Samant et al .(2010), who identified fifty three mango genotype out of sixty - three with two ISSR primers (UBC812 and UBC- 891), meanwhile, ISSR-5 primer identify the lowest number of genotype (17). Moreover, primers UBC- 812, UBC- 891, UBC-808 and $\mathrm{UBC}-836$ were found to be of high value for fingerprinting in mango as they were able to resolve $58,57,55$ and 55 out of 63 selected mango genotype for the study.

\section{REFERENCES}

Agricltural Statistics(2012): Ministry of Agricultural and land Reclamation, Egypt. Vol. $2 \mathrm{~h}$.

Anjum, M.A; S.S.Akhtar and B.Siddique (2014): Physcio-chemical sensory profiling of promising mango cultivars grown in PeriUrban areas of Multan- Pakistan. Pak. J. Bot., 46(1): 191-198.

A.O.A.C. (1980): Official methods of analysis, $13^{\text {th }}$ Ed., Association of official analysis chemists, Washington, D.C., USA.

Barua, H; M.M. Patwary and M.H.Rahman (2013): Performance of Bari mango (Mangifera indica, L.) varieties in Chittagong Region. Bangladesh J. Agril. Res. 38(2): 203-209.
Cao W.; G. Scoles; G.Hucl and R. N. Chibber (1999): The used of RAPD analysis to classify Triticum accessions. Theor. Appl. Genet. 98: 602-607.

Dubois, M.; K.A. Cilles; J.K. Hamilton; P.A. Rober and F. Smith. (1956). Colorimetric method for determination of sugar and related substances. Anal. Chem. 28: 350-356.

Gomez, K.A. and Gomez (1984): Statistical procedures for Agricultural Research. $2^{\text {nd }}$ Edi. John Wiley and Sons. New York. USA.

Hamdard, M.S; M.R. Rafique and U.Farooq (2004): Physcio- chemical characteristics of various mango (Mangifera indica, L.) varieties. J .Agric.42(2): 191 - 199.

Ibrahim, A.M.F and M.N. H.Kholif (1999): The mango (in arabic). Monshaat Almaarif, Alexandria,Egypt.

IPGRI (2006). Descriptors for mango 1989. IPGRI, International plant genetic resource institute, 2006 Rome, Italy.

Machado, M. A.; F. H. D. Coletta; M. L. P. N. Targon and J. J. Pompeu (1996): Genetic relationship of Mediterranean mandarin (Citrus deliciosa Tenore) using RAPD markers. Euphytica 92: 321-326.

Majumder,D.A.N; M.A.Rahim and M.A.Kabir (2011): Studies on physio- morphology, floral biology and fruit characteristics of mango. J. Bangladesh Agril. Univ. 9(2): 187199. 
Majumder, D. A. N.; L. Hassan and M. A. Kabir (2011): Genetic Diversity of mango (Mangifera indica L., Anacardiaceae) detected by RAPD Markers. Inter. J. of Agri. Envir. \& Biotechnolog. (4) 145.

Malik, C.P. and M.P. Singh (1980): Plant enzymology and histo enzymology. A text Manual pp. 276-277. (Kalyani publishers, New Delhi).

Mukesh (2014): Molecular characterization of mango (Mangifera indica L.) using rapd markers. Annals of Horticulture.7:17 - 19 .

Mukherjee, S.K. (1998): Introduction: botany and importance. In. Litz, R.E., ed The Mango: botany Production and Uses, Wallingford: CAB. International, 1-19.

Mukherjee, S.K. (1950) Mango its allopolyploid nature. Nature 166: 196- 197.

Nebauer, S.G.; L. Gastillo-Agudo and J.Segura (2000): An assessment of genetic relationships within the genus Digitalis based on PCR- generated RAPD markers. Theor. Appl. Genet. 100: 1209-1016.

Nielson, G. (1985): The use of isozymes as probes to identify and label plant varieties and cultivars. I n. M. C. Rattazzi, J. G. Scandalios; G.S. Whitt (eds.), Isozymes: Current Topics in Biological and Medical Research. 12: 1 - 32. Alan. R. New York.

Porebski, S.; L. G. Bailey and B. R. Baum (1997): Modification of a CTAB DNA extraction protocol for plants containing high polysaccharides and polyphenol compounds. Plan Mol. Bio. Rep. 15: 8-15.
Ravi, K., R. M. Sharma and R. Kher.(2002): Performance of some mango cultivars under sub-tropical rainfed region of Jammu. Haryana J. Hort. Sci. 31(1-2): 8-10.

Ravindra, K; S. Abhishek; K. K. Anil; K. Brijesh; P. Vipin ; R. M. Singh; K. Mahesh and K. Samal,K.S.; R.C. Jena; S.S. Swain; B. K. Das and P.K.Chand (2012): Evaluation of genetic diversity among commercial cultivars, hybrids and local mango (Mangifera indica L.) genotypes of India using cumulative RAPD and ISSR markers. Euphytica. 185: 195-213.

Samant, D.; A.K. Singh; M. Srivastav and N.K. Singh (2010): Assessment of genetic diversity in mango using inter-simple sequence repeat markers. Indian J. Hort. 67: 1-8.

Saibyasachi, N.C. (2003). RAPD characterization of open pollinated progeny of Mallika mango (Mangifera indica, L.). M.Sc. Thesis, Fac. of Agric., Bangalore Univ.

Wolf, H. T., I. Zuundorf, T. Wincriler, R.,Baues and T.Dingerman(1999). Characterization of Echinacea species and detection of possible adulterations by RAPD analysis Planta Med., 65: $773-774$.

Woodman, A.G. (1941). Food analysis. McGrawHill Book Company, Ince. New York.

Williams, J. G. K.; A. R. Kublik; K. J. Livak, J. A. Rafalsky and S. V. Tingey (1990): DNA polymorphisms amplified by arbitrary primers are useful as genetic markers. Nucl. Acid. Res. (18): 653-655. 


\section{الملخص العربى \\ دراسات فى الأختلافات الوراثية على بعض التراكيب الور اثية للماتجو المتعددة الأجنة والأحادية الأجنة بأستخدام الوسمات المورفولوجية و الجزيئية}

عاطف محمد أبراهيم'، أبو زيد محمود عطا اللة '، نهلة عبد الفتاح عوض ‘هشام محمد الثيشتاوى"

$$
\begin{aligned}
& \text { وسعد أنور على النه } \\
& \text { 'قنسم الفاكهة - كلية الزر اعة - جامعة الاسكندرية - الاسكندرية' }
\end{aligned}
$$

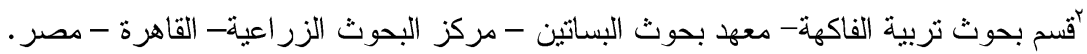

$$
\begin{aligned}
& \text { "معهد بحوث الهندسة الور اثية الزر اعبة - مركز البحوث الزر اعية - القاهرة - مصر. }
\end{aligned}
$$

أجريت هذة الدراسة خلال موسمى 2013 و 2014 على أثنجار مانجو تامه النمو عمرها 8 سنوات وذللك للتهجين

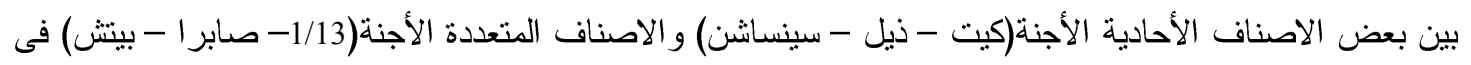
مزرعة قسم الفاكهة الأستو ائية- معهد بحوث البساتين- الجيزة- مصر. تم تقييم الصفات الفيزيائية و الكيميائية للثماربالاضافة إلى أستخدام الوسمات الجزيئية(RAPD). ومن الواضح الفح ان صنف الفئ الكيت سجل أفضل القياسات

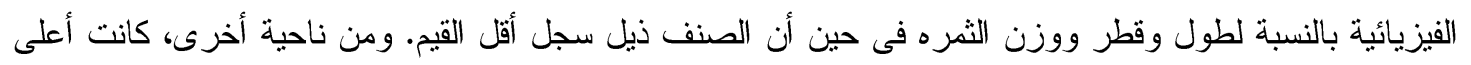

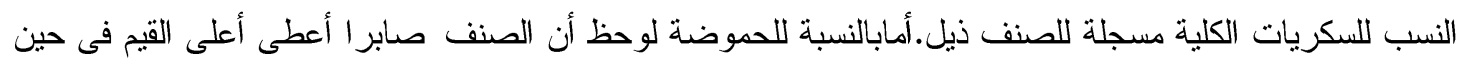
أن الصنف ذيل سجل أقل القيم. وعلاوة على ذلك كانت أعلى النسب ل Vit.C من نصيب الصنف كيت و اقلها فى في

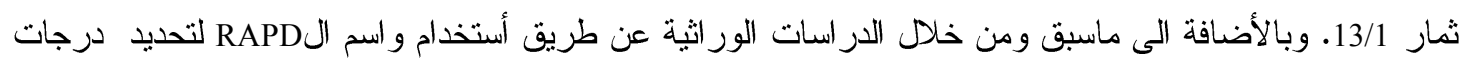
القز ابة الور اثثة وكذلك لتميز وتعريف واسمات فريدة خاصة لستة أصناف مانجو و الهجن الناتجة منها بأستخدام 8

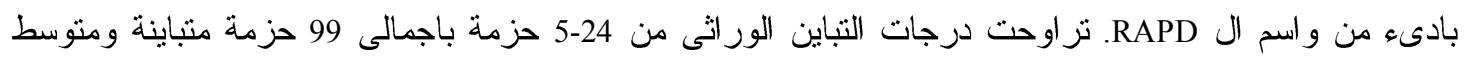
12.3 حزمة/ بادى. كما أوضحت النتائج المتحصل عليها أن أكبر عدد من الحزم(24) نتج من أستخدام البادىء

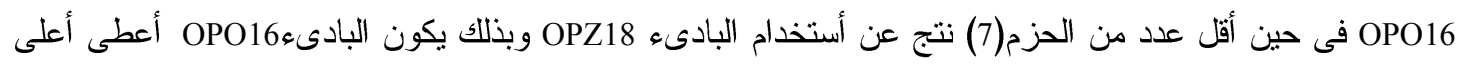
نسبة من الأختلافات الور اثية(100\%). كما وجد أن الهجين H13 ينتمى الى التركيب الورثى كيت. و الهجين H5 كان أقرب للتركيب الور اثى ذيل، فى حين أن الهن(H11, H1, H10, H12) أنتمت الى التركيب الور اثى سينساثن. ومن هذة الدر اسة يتضح أن ثمار صنفى الكيت وذيل من افضل الأصناف المدروسة من حيث الصفات الفيزيائية و الكيميائية و أستخدامها كأمهات للحصول على هجن، كما أن هذة الدراسة تحتاج الى مزيد من الدر اسات على الهن

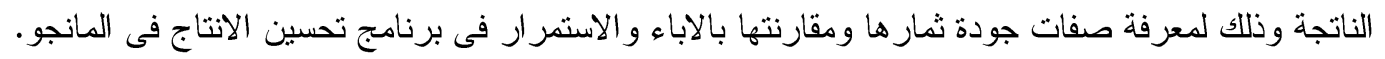

